\title{
Effects of Kiss2 on the Expression of Gonadotropin Genes in the Pituitary of Nile Tilapia (Oreochromis niloticus)
}

\author{
Jin Woo Park', Jung-Hyun Kim', and ${ }^{\dagger} J o o n$ Yeong Kwon² \\ ${ }^{1}$ Jeju Fisheries Research Institute, National Institute of Fisheries Science, Jeju 63610, Korea \\ ${ }^{2}$ Dept. of Aquatic Life Medical Sciences, Sunmoon University, Asan 31460, Korea
}

Received: February 25, 2020

Revised: August 24, 2020

Accepted: September 21, 2020

${ }^{\dagger}$ Corresponding author Joon Yeong Kwon

Dept. of Aquatic Life Medical Sciences, Sunmoon University, Asan 31460, Korea.

Tel: +82-41-530-2284

Fax: +82-41-530-2917

E-mail:jykwon@sunmoon.ac.kr

Copyright $\odot 2020$ The Korean Society of Developmental Biology.

This is an Open Access article distributed under the terms of the Creative Commons Attribution Non-Commercial License (http://creativecommons.org/licenses/ by-nc/4.0/) which permits unrestricted non-commercial use, distribution, and reproduction in any medium, provided the original work is properly cited.

ORCID

Jin Woo Park

https://orcid.org/0000-0003-3604-9810 Jung-Hyun Kim

https://orcid.org/0000-0002-1991-9581

Joon Yeong Kwon

https://orcid.org/0000-0001-8485-0878

Conflict of interests

The authors declare no potential conflict of interest.

Acknowledgements

This work was supported by a grant from the National Institute of Fisheries Science, Korea (R2020005).

\section{Authors' contributions}

Conceptualization: Park JW, Kim JH,

Kwon JY.

Data curation: Park JW.

Formal analysis: Park JW.

Methodology: Park JW, Kim JH, Kwon JY.

Software: Park JW.

Validation: Kwon JY.

Investigation: Park JW, Kim JH.

Writing - original draft: Park JW.

\section{Abstract}

Kisspeptin, expressed mainly in the hypothalamus, stimulates gonadotropin-releasing hormone neurons to facilitate reproduction. In some model animals, the kisspeptin is also expressed in the pituitary. Recently, a pathway has been suggested in which kisspeptin acts directly on the pituitary to secretion of gonadotropin in mammals. In the present study, pituitaries of the Nile tilapia (Oreochromis niloticus) were cultured at different concentrations of kisspeptin-10 (Kp-10, FNYNPLSLRF) for 3 hours to observe the effect of kisspeptin on the expression of follicle-stimulating hormone $\beta$ subunit $(f s h \beta)$ gene and luteinizing hormone $\beta$ subunit $(\mathrm{Ih} \beta)$ gene. Pituitary tissues were cultured with $0.1 \mu \mathrm{M}$ of $\mathrm{Kp}-10$, luteinizing hormone releasing hormone $(\mathrm{LHRH})$, or $\mathrm{LHRH}+\mathrm{Kp}-10$ for 3, 6, 12, and 24 hours to investigate changes in the expression of $f s h \beta$ and $\operatorname{lh} \beta$ mRNA. Pituitaries cultured with high concentration of Kp10 more than $0.1 \mu \mathrm{M}$ for 3 hours exhibited a significant increase of $f \operatorname{sh} \beta$ mRNA expression, but not Ih $\beta$ mRNA. The expression of both $f s h \beta$ and $/ h \beta$ mRNA increased after 6 hours in 0.1 $\mu \mathrm{M}$ of $\mathrm{Kp}-10$ medium in comparison with that in the control medium. Tissues cultured in the $\mathrm{LHRH}$ medium however exhibited increased expression of both genes not only at 6 but also 12 hours. There were no significant differences of $f s h \beta$ and $I h \beta$ gene expression in tissues cultured with LHRH+KP-10 medium compared with the control. These results suggested that although kisspeptin plays an important role in $f \operatorname{sh} \beta$ and $I h \beta$ expression in the pituitary of Nile tilapia, its action is far more complicated than expected.

Keywords: Kisspeptin-10, Pituitary, Tissue culture, Ih $\beta$, fsh $\beta$, Nile tilapia

\section{INTRODUCTION}

Kisspeptin is a peptide translated from the Kiss gene. Following the identification of the Kiss gene, various studies to clarify the function of kisspeptin suggested that it stimulates gonadotropin-releasing hormone $(\mathrm{GnRH})$ neurons in the hypothalamus to promote the secretion of gonadotropin hormone (GtH) (Parhar et al., 2004). However, kisspeptin is expressed in tissues other than the hypothalamus in fish (Oakley et al., 2009), and kisspeptin expression in the pituitary may directly affect reproduction in mammals (Gutiérrez-Pascual et al., 2007; Richard et al., 2008). The Kiss1 and Kiss1 receptor genes are expressed in gonadotrophs in the pituitaries of rats, and their expression can be controlled by oestradiol and GnRH (Richard et al., 2008). 
Writing - review \& editing: Park JW, Kim JH, Kwon JY.

Ethics approval

This article does not require IRB/IACUC approval because there are no human and animal participants.
Although the kisspeptin gene is expressed in the pituitaries of several species of fish and mammals (Escobar et al., 2013; Lehman et al., 2010; Ogawa \& Parhar, 2013; Park et al., 2016), the function of kisspeptin in the pituitary is not clear (Navarro et al., 2005; Smith et al., 2008; Suzuki et al., 2008). Treating the pituitary cells of goldfish (Carassius auratus) with kisspeptin1 stimulated the secretion of luteinizing hormone (LH; Yang et al., 2010), although kisspeptin2 did not affect LH secretion (Li et al., 2009). A direct effect of kisspeptin on the pituitary was observed in the European eel (Anguilla anguilla); treatment of eel pituitary cells with lamprey (Petromyzon marinus) or zebrafish (Danio rerio) kisspeptin peptides reduced luteinizing hormone $\beta$ subunit $(l h \beta$ ) mRNA expression (Pasquier et al., 2011). These experimental results suggest that kisspeptin has a direct, species-specific function in the pituitary.

The pituitary of sexually mature male and female Nile tilapia (Oreochromis niloticus) also exhibited elevated expression of the Kiss2 gene (Ogawa et al., 2013) suggesting a direct or indirect role for kisspeptin in reproduction at the pituitary level. However, the direct effect of kisspeptin on the pituitary of Nile tilapia has not been investigated. Therefore, the present study was performed to investigate the effects of various concentrations of synthetic kisspeptin on gene expression of the follicle-stimulating hormone $\beta$ subunit $(f s h)$ and $l h \beta$, as well as possible effects of incubation time on the pituitary of Nile tilapia.

\section{MATERIALS AND METHODS}

\section{Fish and pituitary extractions}

Fish used in this experiment were juvenile Nile tilapia ( $\mathrm{n}=400$, body length: $8.1 \pm 0.4 \mathrm{~cm}$, body weight: $10.2 \pm 1.4 \mathrm{~g}$ ) that were hatched and raised at Sun Moon University (Asan, Chung Nam, Korea). To minimize the effects of endogenous sex steroids on kisspeptin's action, juvenile tilapia at immature stages $(\mathrm{GSI}<0.25 \%)$ were used in the present study. All fish were raised in a filtered system, at $27 \pm 1^{\circ} \mathrm{C}$, with a photoperiod of 14 hours light: 10 hours dark, and were given dry commercial feed (Woosung, Seoul, Korea) twice daily. Fish were anesthetized with benzocaine $(50 \mathrm{ppm})$ under sterile conditions for pituitary extractions. Extracted pituitaries were placed in 96-multiwell plates with a culture medium ( $\mathrm{pH}$ 7.4) composed of Leibovitz's L15 medium 80\% (v/v) (Gibco ${ }^{\circledR}$ BRL, Bethesda, MD, USA), fetal bovine serum (10\%), penicillin (100 IU/mL), and streptomycin $(100 \mu \mathrm{g} / \mathrm{mL})$. To stabilize the tissue, the pituitaries were cultured in the dark at $27^{\circ} \mathrm{C}$ for 3 hours. All animal maintenance and experimental procedures were approved by the Institutional Animal Care and Use Committee of Sun Moon University.

\section{Peptides}

A Kiss2 peptide (Kp-10, FNYNPLSLRF-NH2) was synthesized and purified using highperformance liquid chromatography according to the manufacturer's procedures (Peptron, Daejeon, Korea). The purity of peptides used in study was $>95 \%$. The peptide was diluted in phosphatebuffered saline (PBS).

\section{In vitro pituitary culture}

Pituitary culture experiments were conducted with different concentrations of Kp-10 and differing incubation times. The composition of culture medium were decided according to a previous report (Jin et al., 2016). First, for concentration experiments, stabilized pituitaries were placed in culture medium (Leibovitz's L15 medium 80\% (v/v), fetal bovine serum 10\%, penicillin $100 \mathrm{IU} / \mathrm{mL}$, streptomycin $100 \mu \mathrm{g} / \mathrm{mL}, \mathrm{pH}$ 7.4) with different concentrations of Kp-10 (0, 0.001, 
$0.01,0.1,1$, or $10 \mu \mathrm{M})$ for 3 hours ( $\mathrm{n}=5-9$ per experimental group).

For incubation time experiments, stabilized pituitaries were placed into culture medium (Leibovitz's L15 medium 80\% (v/v), fetal bovine serum 10\%, penicillin $100 \mathrm{IU} / \mathrm{mL}$, streptomycin $100 \mu \mathrm{g} / \mathrm{mL}, \mathrm{pH}$ 7.4) with either $\mathrm{Kp}-10(0.1 \mu \mathrm{M})$, salmon luteinizing hormone releasing hormone (LHRH) $(0.1 \mu \mathrm{M})$ (Sigma-Aldrich, St. Louis, MO, USA), or both Kp-10 and LHRH (Kp$10+\mathrm{LHRH})(0.1 \mu \mathrm{M})$ for $3,6,12$, or 24 hours ( $\mathrm{n}=5-9$ per experimental group). The concentration used for incubation time experiments was $0.1 \mu \mathrm{M}$, selected because it was the concentration that affected the gene expression of $\mathrm{GtH}$ subunits in Kp-10 concentration experiments. As a control, stabilized pituitaries were cultured in the base medium in the absence of peptides. All experimental pituitary tissues were stored at $-70^{\circ} \mathrm{C}$ prior to total RNA extraction.

\section{Pituitary viability test}

Trypan blue staining was used to verify the viability of pituitary function under the conditions used in culture experiments. Live pituitaries (control), dead pituitaries (immersion in distilled water), and pituitaries cultured for 24 hours in the experimental culture medium were stained with $0.4 \%$ trypan blue for 30 minutes ( $\mathrm{n}=3$ per experimental group). In addition, to identify any tissue damage from the trypan blue toxin, live pituitary tissue was stained with $0.4 \%$ trypan blue for an hour $(\mathrm{n}=3)$. All stained pituitaries were washed with PBS until unincorporated stain was removed, and were observed using a 3D optical microscope (EZ4, Leica, Germany).

\section{RNA extraction and CDNA synthesis}

Total RNA was extracted using TRI reagent ${ }^{\circledR}$ (Invitrogen, Waltham, Ma, USA). All reagents used in cDNA synthesis were purchased from Promega (Madison, WI, USA). Each total RNA (1 $\mu \mathrm{g})$ sample was treated with DNase I (RQ1 RNase-free DNase) to remove genomic DNA and, then, reverse transcribed according to the manufacturer's protocol using Oligo $(\mathrm{dT})_{15}$ primer, 10 $\mathrm{mM}$ dNTP mix, M-MLV (Moloney murine leukaemia virus) reverse transcriptase and the buffer provided.

\section{Quantitative real-time PCR (qRT-PCR)}

qRT-PCR was performed to quantify changes in the expression of $f s h \beta$ and $l h \beta$ in the pituitary of Nile tilapia. Pituitaries were cultured with different concentrations of Kp-10 and were also cultured with $0.1 \mu \mathrm{M} \mathrm{Kp}-10, \mathrm{LHRH}$, and Kp-10+LHRH for various lengths of time. All primers used in the experiment were produced using Beacon Designer (Bio-Rad, Hercules, CA, USA) (Table 1). All qRT-PCR reactions were conducted using Topreal ${ }^{\mathrm{TM}}{ }_{\mathrm{qPCR}} 2 \mathrm{X}$ PreMIX SYBR Green (Enzynomics, Daejeon, Korea) and analysed with the CFX96 Touch ${ }^{\text {TM }}$ Real-Time PCR Detection System (Bio-Rad). Reaction conditions for qRT-PCR were as follows: Initial denaturation at $95^{\circ} \mathrm{C}$ for 15 minutes, followed by 45 amplification cycles of denaturation at $95^{\circ} \mathrm{C}$

Table 1. Primers used for quantitative real-time PCR analysis

\begin{tabular}{cll}
\hline \hline Genes & Primer & \multicolumn{1}{c}{ Sequences } \\
\hline LHB (AY294016) & Forward & 5'-GCT GTC ACC CAG TAG AGA-3' \\
& Reverse & 5'-TTG CTG AAT GGT ATC TTG ATG A-3' \\
\hline \multirow{2}{*}{ FSH $\beta$ (AY294015) } & Forward & 5'-ACT TCA TTC ATA CTG ACG ACT G-3' \\
& Reverse & 5'-TTG CTC TGT GTA TTT CAC CTC-3' \\
\hline \multirow{2}{*}{ GAPDH (JN381952) } & Forward & 5'-TTAAGG AAG CCG TCAAGAAG-3' \\
& Reverse & 5'-CAG CAC CAG CAT CAAAGA-3' \\
\hline
\end{tabular}


for 15 seconds, annealing at $60^{\circ} \mathrm{C}$ for 15 seconds, and elongation at $72{ }^{\circ} \mathrm{C}$ for 30 seconds. Following the reaction, the melting curve was analysed. GAPDH mRNA was used as the reference and CFX Manager $^{\mathrm{TM}}$ (Bio-Rad) was used for relative quantification using the $2^{-\Delta \Delta \mathrm{Ct}}$ method. All samples were analysed a minimum of two times.

\section{Statistical analysis}

The expression levels of $f s h \beta$ and $l h \beta$ (mean \pm SEM) in pituitary tissues obtained from culture experiments using different concentrations of $\mathrm{Kp}-10$ were analysed using a one-way ANOVA and Duncan's multiple range test $(p<0.05)$. The expression of $f s h$ and $l h \beta$ (mean \pm SEM) obtained from culture experiments with various incubation times in media with $\mathrm{Kp}-10$, LHRH, or Kp$10+\mathrm{LHRH}$ were analysed using an independent $t$-test $(p<0.05)$ on each experimental group and the control group $(0 \mu \mathrm{M})$. All statistical analyses were performed using SPSS, version 18.0 (IBM, Armonk, NY, USA).

\section{RESULTS}

\section{Pituitary viability test}

There were distinct differences between live, damaged, and dead pituitary tissues (Fig. 1). Pituitaries cultured in the medium for 24 hours were not stained with trypan blue, and neither were live pituitaries. However, damaged and dead tissues were heavily stained with trypan blue. These results indicate that there was no damage to pituitary tissues during pituitary culture experiments for 24 hours.

\section{Actions of kisspeptin on the pituitary}

There was no difference in the expression of the $f s h \beta$ gene (mean $\pm \mathrm{SEM}$ ) in pituitary tissues in culture with Kp-10 at concentrations lower than $0.01 \mu \mathrm{M}$ for 3 hours; however, levels of expression increased in response to concentrations higher than $0.1 \mu \mathrm{M}$ (Fig. 2). In contrast, levels of $l h \beta$ mRNA did not exhibit significant differences in response to varying concentrations of $\mathrm{Kp}-10$.

Regarding incubation times, we observed a significant increase in the expression of $f s h$ mRNA at 3 and 6 hours, and an increase in the expression of $l b \beta$ mRNA at 6 hours, compared with the control group of pituitaries cultured in the presence of $\mathrm{Kp}-10(0.1 \mu \mathrm{M})$ (Fig. 3). However, there were no significant increases at 12 or 24 hours for either gene compared with that in the control group (Fig. 3). In pituitaries cultured in the presence of LHRH $(0.1 \mu \mathrm{M})$, there were significant increases in the expression of $f s h \beta$ and $l h \beta$ mRNA at 6 and 12 hours, compared with that reported for the control group, but no differences at 24 hours (Fig. 4). Lastly, there were no

\begin{tabular}{|c|c|c|c|c|c|}
\hline Tissue & Live tissue & Live tissue & Damaged tissue & $\begin{array}{c}\text { Dead tissue } \\
\text { (25 hours in distilled water) }\end{array}$ & $\begin{array}{c}\text { Live tissue } \\
(24 \text { hours in culture medium) }\end{array}$ \\
\hline Staining time & - & 30 minutes & $\begin{array}{c}1 \text { hour } \\
\text { (over staining })\end{array}$ & 30 minutes & 30 minutes \\
\hline Dorsal & & & & & \\
\hline
\end{tabular}

Fig. 1. Pituitary tissues stained with trypan blue. 

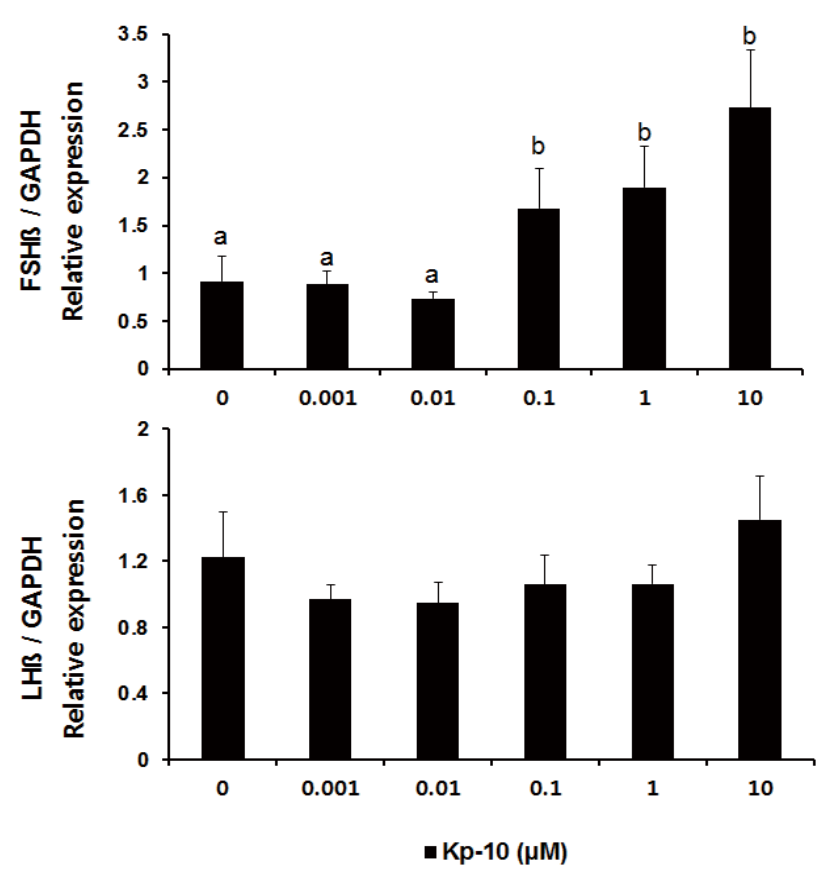

Fig. 2. Relative abundance of $f s h \beta$ and $\operatorname{lh} \beta$ mRNA in Nile tilapia pituitary tissues in response to varying concentrations of kisspeptin-10. Pituitary tissues were subjected to treatment with different concentrations of kisspeptin-10 (Kp-10, $0-10 \mu \mathrm{M})$ for 3 hours. The relative abundance of the mRNA was measured by the comparative threshold cycle method using qRT-PCR and normalized to the quantity of GAPDH mRNA. Results are expressed as mean \pm SEM $(n=4-9)$. Different letters above the bars represent significant differences between the pituitary groups treated with different concentrations of $\mathrm{Kp}-10(p<0.05)$.

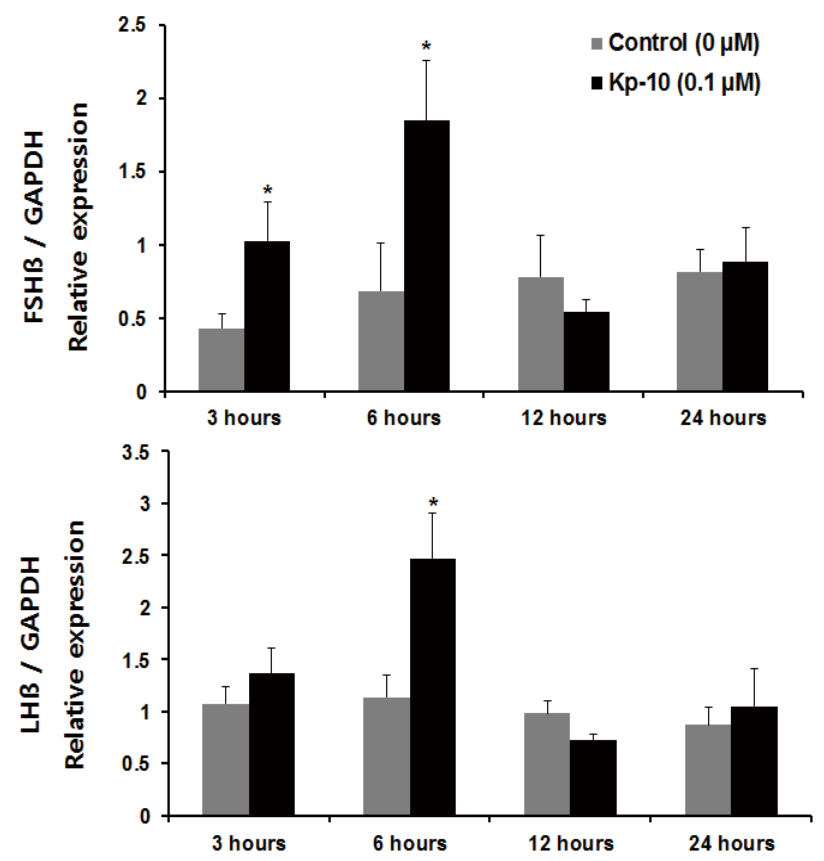

Fig. 3. Relative abundance of $f s h \beta$ and $I h \beta$ mRNA in Nile tilapia pituitary tissues in response to kisspeptin-10 over time. Pituitary tissues were treated with kisspeptin-10 $(\mathrm{Kp}-10,0.1 \mu \mathrm{M})$ for $3,6,12$, or 24 hours. The relative abundance of mRNA was measured by the comparative threshold cycle method using qRT-PCR and normalized to the quantity of GAPDH mRNA. Results are expressed as mean \pm SEM $(n=4-9)$. Asterisks $\left(^{*}\right)$ indicate significant differences in comparison with the control group at each incubation period $(p<0.05)$. 

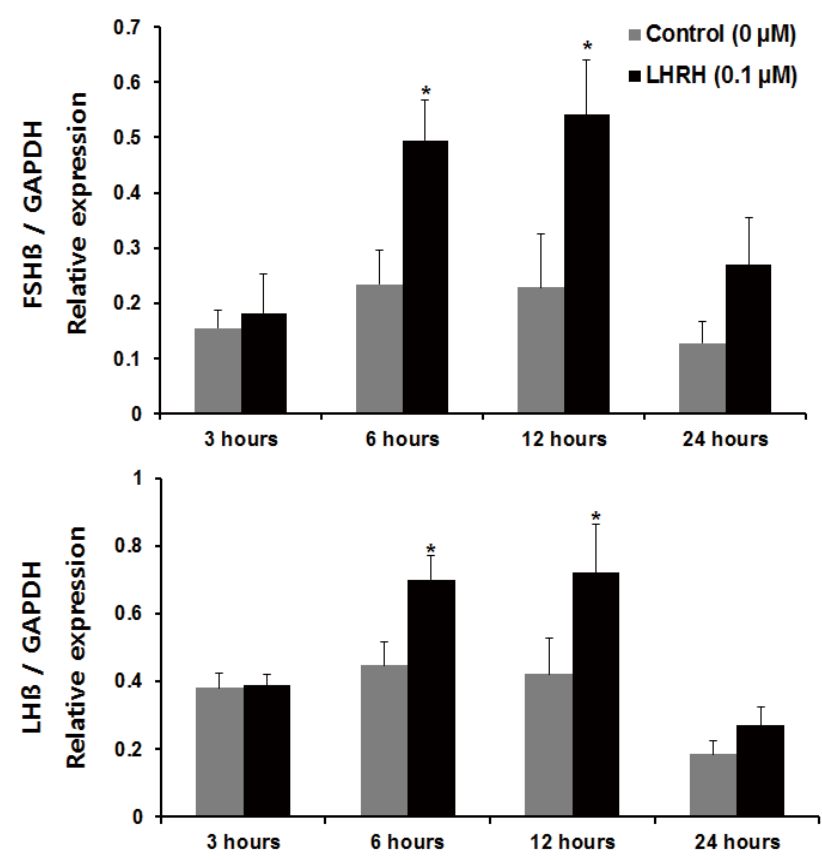

Fig. 4. Relative abundance of $f s h \beta$ and $I h \beta$ mRNA in Nile tilapia pituitary tissues in response to LHRH over time. Pituitary tissues were treated with LHRH $(0.1 \mu \mathrm{M})$ for $3,6,12$, or 24 hours. The relative abundance of mRNA was measured by the comparative threshold cycle method using qRT-PCR and normalized to the quantity of GAPDH mRNA. Results are expressed as mean \pm SEM $(n=4-9)$. Asterisks $\left(^{*}\right)$ indicate significant differences in comparison with the control group at each incubation period $(p<0.05)$. $\mathrm{LHRH}$, luteinizing hormone releasing hormone.

significant differences in the expression of $f s h \beta$ and $l h \beta$ mRNA at any time when pituitaries were cultured in the presence of $\mathrm{Kp}-10+\mathrm{LHRH}(0.1 \mu \mathrm{M})$, although the overall expression of these genes was higher than that of the control group (Fig. 5).

\section{DISCUSSION}

In this study, we investigated that kisspeptin could have a direct effect on the expression of $\mathrm{GtH}$ subunits in the Nile tilapia pituitary. The results show that treatment with Kp-10 increases the expression of the subunits of two gonadotropin genes in the pituitary of the Nile tilapia. However, the present study demonstrates that treatment with $\mathrm{Kp}-10$ at different concentrations in the culture medium and for varying incubation times had different effects on the subunits of the gonadotropin genes. Incubating pituitary tissues of the Nile tilapia with at $0.1-10 \mu \mathrm{M} \mathrm{Kp}-10$ for 3 hours increased $f s h$ mRNA levels, whereas no differences were detected in the levels of $l h \beta$ mRNA expression (Fig. 2). However, levels of $t h \beta$ mRNA expression increased after 6 hours of incubation at a constant concentration of $0.1 \mu \mathrm{M} \mathrm{Kp}-10$ (Fig. 3). This finding could be the result of differences in the timing of $l h \beta$ expression, due to the delayed transcription of $l h \beta$ mRNA in response to kisspeptin. This phenomenon has also been observed in goldfish; kisspeptin treatment did not have any effects on $l h \beta$ mRNA expression after 180 minutes of incubation, but increased after 24 hours of incubation, suggesting the possibility of delayed gene transcription (Yang et al., 2010). However, an alternative explanation may involve differences in the effects of kisspeptin on the expression of the subunits of gonadotropin genes in the pituitary.

Increased expression of the two gonadotropin $\beta$-subunits relative to the control group was 

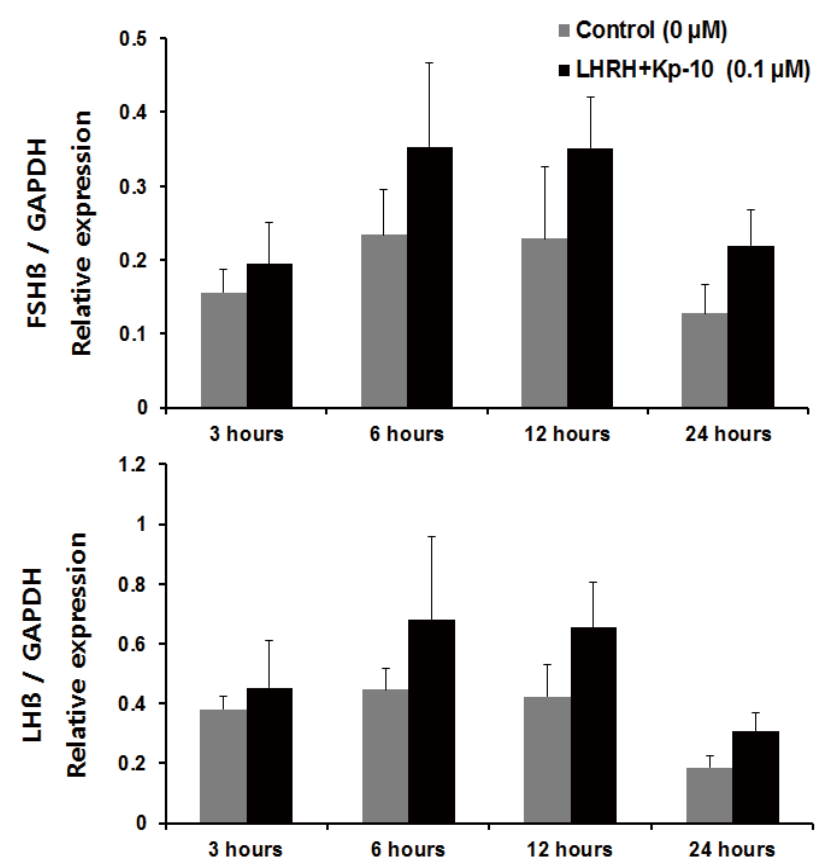

Fig. 5. Relative abundance of $f s h \beta$ and $\operatorname{lh} \beta$ mRNA in Nile tilapia pituitary tissues in response to kisspeptin-10+LHRH. Pituitary tissues were treated with kisspeptin-10+LHRH $(0.1 \mu \mathrm{M})$ for $3,6,12$, or 24 hours. The relative abundance of mRNA was measured by the comparative threshold cycle method using qRT-PCR and normalized to the quantity of GAPDH mRNA. Results are expressed as mean \pm SEM $(n=4-9)$. LHRH, luteinizing hormone releasing hormone.

observed in response to treatment with $\mathrm{Kp}-10$ after 6 hours of incubation, but no significant increase was seen at 12 or 24 hours for either gene relative to the control group. As shown by the viability experiment, this decrease in gene expression is not likely to be the result of damage to pituitary tissue. The kiss gene's receptor is $G$ protein-coupled receptor 54 (GPR 54) (Ohtaki et al., 2001). Studies of GPR54 receptor desensitization in female mice have reported that continuous kisspeptin treatment can reduce levels of LH and FSH initially elevated by kisspeptin exposure (Roa et al., 2008). Considering these facts, long-term treatment with kp-10 may lead to GPR54 receptor desensitization in the pituitary gland of Nile tilapia. However, it is difficult to explain the decrease in gonadotropin $\beta$-subunits over time based on the results of this study alone. Thus, further studies are needed.

In vertebrates, $\mathrm{GnRH}$ is known to be an important regulator of $\mathrm{GtH}$ secretion in the pituitary. Treatment with $\mathrm{GnRH}$ in mammalian pituitary cells increased $\mathrm{LH}$ secretion to a greater extent than kisspeptin treatment (Gutiérrez-Pascual et al., 2007), and GnRH was a potent regulator of reproductive processes. Similarly, in the present study, the increased expression of gonadotropin $\beta$-subunits in the presence of LHRH was maintained for a longer period than that in tissues cultured in Kp-10-supplemented medium. In the present study, LHRH was used as a positive control, as $\mathrm{GnRH}$ is known to stimulate $\mathrm{GtH}$ secretion in vertebrates, including teleosts. Our findings suggest that $\mathrm{GnRH}$ is more effective at increasing the mRNA expression of the gonadotropin $\beta$-subunits in the pituitary of the Nile tilapia than kisspeptin. This difference might be explained by the fact that kisspeptin mainly acts on the hypothalamus; its action in the pituitary is only auxiliary.

In the present study, kisspeptin and LHRH effectively increased the mRNA expression of $f_{s h} \beta$ and $l h \beta$. However, combined treatment with kisspeptin and LHRH peptides did not 
result in significant increases in the expression levels. This result could be explained as follows. First, when two substances with similar biological effects act simultaneously, they may offset each other, producing an antagonistic effect. Specifically, as LHRH and kisspeptin have the same effect of increasing $\mathrm{GtH}$ subunit expression in the pituitary gland, a compensating reaction may have occurred between the two molecules. Similarly, in in vivo experiments on yellow kingfish (Seriola lalandi), administration of Kiss1 alone increased GtH subunit levels, but administration of both Kiss1 and Kiss2 together did not lead to any such increase (Nocillado et al., 2013). Second, kisspeptin may have affected GtH subunit expression by reducing the sensitivity of $\mathrm{GnRH}$ secretion. In the known $\mathrm{GtH}$ secretion pathways, kisspeptin stimulates $\mathrm{GnRH}$ neurons in the hypothalamus, causing the secretion of $\mathrm{GnRH}$, which in turn stimulates $\mathrm{GtH}$ secretion in the pituitary gland. However, in the present study, the combination of kisspeptin administration with continuous $\mathrm{GnRH}$ stimulation may have reduced the sensitivity of $\mathrm{GnRH}$ secretion, thus affecting $\mathrm{GtH}$ subunit expression as well. A study that used rhesus monkeys (Macaca mulatta) reported that long-term kisspeptin treatment decreased the sensitivity of $\mathrm{GnRH}$ secretion in the hypothalamus (Seminara et al., 2006). In addition, several studies on mammals have reported that continuous kisspeptin treatment downregulates hormones of the reproductive axis (Thompson et al., 2006; Ramaswamy et al., 2007). In fish case, in vivo experiments on striped bass (Morone saxatilis), $\mathrm{GnRH}$ showed a decreasing trend as the concentration of administered Kiss2 was increased (Zmora et al., 2012). Furthermore, in in vitro experiments in striped bass pituitary cells, levels of $\mathrm{GnRH}$ tended to decrease as the concentration of administered Kiss2 was increased (Zmora et al., 2015). These results suggest that the expression of kisspeptin and GnRH may have mutual effects. However, the results of the present study do not suggest an explanation for either antagonism or synergism between $\mathrm{GnRH}$ and kisspeptin in the Nile tilapia, and thus further research is needed.

To summarize, we investigated the direct regulatory function of kisspeptin on $f_{s h} \beta$ and $l h \beta$ in the pituitary of the Nile tilapia at different concentrations and incubation times. The results showed an increase in the expression of $f_{s h} \beta$ and $l b \beta$ in pituitaries cultured in $\mathrm{Kp}-10(0.1 \mu \mathrm{M})$ for 6 hours and in LHRH $(0.1 \mu \mathrm{M})$ after 6 and 12 hours of incubation. Pituitary tissues cultured in a mixed medium of LHRH and Kp-10 $(0.1 \mu \mathrm{M})$ did not show significant increases in the expression of $f_{s h} \beta$ and $l h \beta$. These results provide experimental evidence for the direct function of kisspeptin on the gonadotropins $f s h \beta$ and $l h \beta$ in the Nile tilapia, excluding indirect effects via the hypothalamus. The findings suggest that there may be an additional reproductive pathway apart from the existing one linking the hypothalamus, pituitary, and gonads. It is also possible that the Kiss gene found in the pituitary might perform a function different from that of the Kiss gene found in the hypothalamus. However, our findings do not sufficiently illuminate the function of the Kiss gene in the pituitary. Yang et al. (2010) reported that kisspeptin in the pituitary of goldfish stimulates the secretion of prolactin and growth hormone, suggesting that it might be performing other functions than mere reproduction. Follow-up studies are needed to further clarify the function of the Kiss gene in the pituitary of Nile tilapia.

\section{REFERENCES}

Escobar S, Felip A, Gueguen MM, Zanuy S, Carrillo M, Kah O, Servili A (2013) Expression of kisspeptins in the brain and pituitary of the European sea bass (Dicentrarchus labrax). J Comp Neurol 521:933-948.

Gutiérrez-Pascual E, Martínez-Fuentes AJ, Pinilla L, Tena-Sempere M, Malagón MM, Castaño JP (2007) Direct pituitary effects of kisspeptin: Activation of gonadotrophs and somatotrophs 
and stimulation of luteinising hormone and growth hormone secretion. J Neuroendocrinol 19:521-530.

Jin YH, Park JW, Kim JH, Kwon JY (2016) Neurokinin B-related peptide suppresses the expression of GnRH I, Kiss2 and tac3 in the brain of mature female Nile tilapia Oreochromis niloticus. Dev Reprod 20:51-61.

Lehman MN, Merkley CM, Coolen LM, Goodman RL (2010) Anatomy of the kisspeptin neural network in mammals. Brain Res 1364:90-102.

Li S, Zhang Y, Liu Y, Huang X, Huang W, Lu D, Zhu P, Shi Y, Cheng CH, Liu X, Lin H (2009) Structural and functional multiplicity of the kisspeptin/GPR54 system in goldfish (Carassius auratus).J Endocrinol 201:407-418.

Navarro VM, Castellano JM, Fernández-Fernández R, Tovar S, Roa J, Mayen A, Barreiro ML, Casanueva FF, Aguilar E, Dieguez C, Pinilla L, Tena-Sempere M (2005) Effects of KiSS1 peptide, the natural ligand of GPR54, on follicle-stimulating hormone secretion in the rat. Endocrinology 146:1689-1697.

Nocillado JN, Zohar Y, Biran J, Levavi-Sivan B, Elizur A (2013) Chronic kisspeptin administration stimulated gonadal development in pre-pubertal male yellowtail kingfish (Seriola lalandi; Perciformes) during the breeding and non-breeding season. Gen Comp Endocrinol 191:168176.

Oakley AE, Clifton DK, Steiner RA (2009) Kisspeptin signaling in the brain. Endocr Rev 30:713743.

Ogawa S, Ng KW, Xue X, Ramadasan PN, Sivalingam M, Li S, Levavi-Sivan B, Lin H, Liu X, Parhar IS (2013) Thyroid hormone upregulates hypothalamic kiss2 gene in the male Nile tilapia, Oreochromis niloticus. Front Endocrinol (Lausanne) 4:184.

Ogawa S, Parhar IS (2013) Anatomy of the kisspeptin systems in teleosts. Gen Comp Endocrinol 181:169-174.

Ohtaki T, Shintani Y, Honda S, Matsumoto H, Hori A, Kanehashi K, Terao Y, Kumano S, Takatsu Y, Masuda Y, Ishibashi Y, Watanabe T, Asada M, Yamada T, Suenaga M, Kitada C, Usuki S, Kurokawa T, Onda H, Nishimura O, Fujino M (2001) Metastasis suppressor gene KiSS-1 encodes peptide ligand of a G-protein-coupled receptor. Nature 411:613-617.

Parhar IS, Ogawa S, Sakuma Y (2004) Laser-captured single digoxigenin-labeled neurons of gonadotropin releasing hormone types reveal a novel $\mathrm{G}$ protein-coupled receptor (Gpr54) during maturation in Cichlid fish. Endocrinology 145:3613-3618.

Park JW, Jin YH, Oh SY, Kwon JY (2016) Kisspeptin2 stimulates the HPG axis in immature Nile tilapia (Oreochromis niloticus). Comp Biochem Physiol B Biochem Mol Biol 202:31-38.

Pasquier J, Lafont AG, Leprince J, Vaudry H, Rousseau K, Dufour S (2011) First evidence for a direct inhibitory effect of kisspeptins on LH expression in the eel, Anguilla anguilla. Gen Comp Endocrinol 173:216-225.

Ramaswamy S, Seminara SB, Pohl CR, DiPietro MJ, Crowley WF, Plant TM (2007) Effect of continuous intravenous administration of human metastin 45-54 on the neuroendocrine activity of the hypothalamic-pituitary-testicular axis in the adult male rhesus monkey (Macaca mulatta). Endocrinology 148:3364-3370.

Richard N, Galmiche G, Corvaisier S, Caraty A, Kottler ML (2008) KiSS-1 and GPR54 genes are co-expressed in rat gonadotrophs and differentially regulated in vivo by oestradiol and gonadotrophin-releasing hormone. J Neuroendocrinol 20:381-393.

Roa J, Aguilar E, Dieguez C, Pinilla L, Tena-Sempere M (2008) New frontiers in kisspeptin/ GPR54 physiology as fundamental gatekeepers of reproductive function. Front Neuroendocrinol 29:48-69. 
Seminara SB, Dipietro MJ, Ramaswamy S, Crowley WF, Plant TM (2006) Continuous human metastin 45-54 infusion desensitizes $\mathrm{G}$ protein-coupled receptor 54-induced gonadotropinreleasing hormone release monitored indirectly in the juvenile male Rhesus monkey (Macaca mulatta): A finding with therapeutic implications. Endocrinology 147:2122-2126.

Smith JT, Rao A, Pereira A, Caraty A, Millar RP, Clarke IJ (2008) Kisspeptin is present in ovine hypophysial portal blood but does not increase during the preovulatory luteinizing hormone surge: Evidence that gonadotropes are not direct targets of kisspeptin in vivo. Endocrinology 149:1951-1959.

Suzuki S, Kadokawa H, Hashizume T (2008) Direct kisspeptin-10 stimulation on luteinizing hormone secretion from bovine and porcine anterior pituitary cells. Anim Reprod Sci 103:360365.

Thompson EL, Murphy KG, Patterson M, Bewick GA, Stamp GWH, Curtis AE, Cooke JH, Jethwa PH, Todd JF, Ghatei MA, Bloom SR (2006) Chronic subcutaneous administration of kisspeptin-54 causes testicular degeneration in adult male rats. Am J Physiol Endocrinol Metab 291:E1074-E1082.

Yang B, Jiang Q, Chan T, Ko WK, Wong AO (2010) Goldfish kisspeptin: Molecular cloning, tissue distribution of transcript expression, and stimulatory effects on prolactin, growth hormone and luteinizing hormone secretion and gene expression via direct actions at the pituitary level. Gen Comp Endocrinol 165:60-71.

Zmora N, Stubblefield J, Zulperi Z, Biran J, Levavi-Sivan B, Muñoz-Cueto JA, Zohar Y (2012) Differential and gonad-stage dependent roles of kisspeptin1 and kisspeptin2 in reproduction in the modern teleosts Morone species. Biol Reprod 86:177.

Zmora N, Stubblefield JD, Wong TT, Levavi-Sivan B, Millar RP, Zohar Y (2015) Kisspeptin antagonists reveal Kisspeptin 1 and Kisspeptin 2 differential regulation of reproduction in the teleost, Morone saxatilis. Biol Reprod 93:76. 